Check for updates

Cite this: Mater. Adv., 2021, 2, 2120

Received 28th November 2020, Accepted 10th February 2021

DOI: $10.1039 / \mathrm{d} 0 \mathrm{ma} 00932 f$

rsc.li/materials-advances

\title{
A binary mixed polymer brush coating with adjusted hydrophobic property to control protein adsorption $\dagger$
}

\author{
Chaoshi Chen, ${ }^{a}$ Muhammad Atif, (D) ${ }^{a}$ Kang He, ${ }^{a}$ Miao Zhang, (D) ${ }^{a}$ Lijuan Chen (D) ${ }^{b}$ \\ and Yanmei Wang iD *a
}

\begin{abstract}
In this work, binary mixed polymer brushes based on poly[(2-methyl-2-oxazoline)-random-glycidyl methacrylate] (PMOXA-r-GMA) and poly(glycidyl methacrylate)-block-poly( $N$-isopropyl acrylamide)block-polystyrene (PGMA-b-PNIPAM- $b$-PSt) were used as thermoresponsive coating to control protein adsorption. Firstly, PMOXA-r-GMA was synthesized via cationic ring opening polymerization of 2-methyl-2-oxazoline followed by its copolymerization with glycidyl methacrylate (GMA); PGMA-bPNIPAM- $b$-PSt was synthesized by reversible addition-fragmentation chain transfer polymerization of GMA, $N$-isopropyl acrylamide, and styrene sequentially. Then the mixed brushes were fabricated successfully by spin coating the mixture of PMOXA-r-GMA and PGMA-b-PNIPAM- $b$-PSt solutions onto silicon or glass substrates followed by an annealing protocol using GMA segments as an anchor. Afterwards, the investigation for adjusting the hydrophobic property of mixed brushes was performed. The results showed that when the environmental temperature is lower than the lower critical solution temperature (LCST) of PNIPAM, the tethered PNIPAM blocks are swollen and could bring the hydrophobic PSt block with optimum molar mass to the surface; when the environmental temperature is higher than the LCST of PNIPAM, the PNIPAM blocks collapse and could bring the hydrophobic block inside the hydrophilic PMOXA grafted polymer layer. Finally, the protein adsorption on mixed polymer brushes was investigated using a fluorescein isothiocyanate-labelled protein assay and ellipsometrys. The results showed that under the optimum molar mass of PSt block, mixed brushes could adsorb proteins in large quantities below the LCST of PNIPAM, and display resistance to protein adsorption above the LCST of PNIPAM.
\end{abstract}

\section{Introduction}

Controlling the hydrophobic interaction between surfaces and proteins in an aqueous environment is important for it could control protein adsorption which is the first step of surface fouling. ${ }^{1-9}$ Stimuli-responsive surfaces are usually used to control the level of hydrophobic interactions between surfaces and proteins due to its switching of hydrophobic/hydrophilic properties upon environment stimulus. ${ }^{10-14}$ The responsive surfaces could be obtained by grafting one end of polymer chains to the surface forming polymer brushes. Among the polymer brushes, binary mixed polymer brushes composed of a

\footnotetext{
${ }^{a}$ CAS Key Laboratory of Soft Matter Chemistry, Department of Polymer Science and Engineering, University of Science and Technology of China, Hefei 230026,

P. R. China. E-mail: wangyanm@ustc.edu.cn

${ }^{b}$ College of Materials and Chemical Engineering, West Anhui University,

Luan 237012, P. R. China

$\dagger$ Electronic supplementary information (ESI) available. See DOI: 10.1039/d0ma00932f
}

hydrophilic part and an environmental responsive part have drawn more attention as its antifouling ability can be adjusted by switching the surface property between hydrophilic and hydrophobic behavior by changing the environmental stimuli (temperature, $\mathrm{pH}$, ionic strength (I), etc.). ${ }^{15-22}$ Hoy and coworkers prepared mixed polymer brushes made of a hydrophilic homopolymer, poly(ethylene oxide) (PEO, also known as poly(ethylen glycol) (PEG)), and an amphiphilic block copolymer, polystyrene$b$-poly(acrylic acid) (PSt- $b$-PAA). ${ }^{23}$ In which, the PSt- $b$-PAA copolymer was grafted to the surface via the reactive PAA part, and the hydrophobic block, PSt as a hydrophobic probe, is immiscible with PAA and PEG. They demonstrated that the hydrophobic property of the created mixed brushes provided by the PSt probe can be adjusted via PSt domains up or down with respect to the top surface through variation of the PAA swelling depending on external stimuli $(\mathrm{pH}, \mathrm{I}$, and the presence of $\mathrm{Ca}^{2+}$ ), and the actuation of the hydrophobic domains in the brushes can be used to tune bovine fibrinogen adsorption on and off. 
Although PEO and its corresponding derivatives have been used widely as antifouling materials because of their great hydrophilic properties, PEO is known to undergo degradation especially in a physiological environment. ${ }^{24}$ Recently, poly(2methyl-2-oxazoline)(PMOXA), a peptidomimetic polymer, has attracted interest for its similar properties (e.g. hydrophilicity and biocompatibility) to PEG and less degradation than PEG. ${ }^{25-29}$ Cavallaro and coworkers reported that the films developed via plasma deposition of 2-methyl-2-oxazoline (MOXA) could resist the adsorption of Staphylococcus epidermidis and cells by more than $90 \%$ regardless of the type of substrate used. ${ }^{30}$ Bai and coworkers developed poly(2-methyl-2-oxazoline-random-glycidyl methacrylate) (PMOXA-r-GMA) comb copolymers. ${ }^{31}$ The PMOXA based coating could then be prepared by a simple annealing protocol of PMOXA-r-GMA on silicon/glass surfaces by using GMA segments as the anchor, because the epoxide groups of glycidyl methacrylate (GMA) segments can not only react with functional groups (i.e., Si-OH) on the surface of silicon/glass, but perform self-crosslinking with each other as well. ${ }^{32-34}$ The prepared coatings possess strong stability and excellent bovine serum albumin (BSA) resistant ability as well. The stimuliresponsive polymer could undergo a rapid conformational change in response to an external stimulus (e.g., temperature, light, redox signal, magnetic field, $\mathrm{pH}$, ionic strength, or a specific molecule), resulting in the switching of the surface functionality on/off. ${ }^{11,14,35-37}$ Among them, poly( $N$-isopropyl acrylamide) (PNIPAM), a thermoresponsive polymer, has received extensive attention due to its lower critical solution temperature (LCST) of $32{ }^{\circ} \mathrm{C}$ close to body temperature. When the environmental temperature is lower than $32{ }^{\circ} \mathrm{C}$, PNIPAM chains swell due to the strong hydrogen bond formed between the water molecules and the PNIPAM chains. When the environmental temperature is higher than $32{ }^{\circ} \mathrm{C}$, the thermal dissociation of water molecules from the hydrated polymer chains can lead to the intrinsic affinity of PNIPAM chains, leading to the lessening of the hydrogen bond between water molecules and the PNIPAM chains; as result, PNIPAM chains shrink and display hydrophobic behavior. ${ }^{38-43}$

Inspired by the stability and low fouling ability of PMOXA based coatings and swelling/deswelling behaviors of PNIPAM chains with temperature, herein our purpose is to create binary mixed polymer brushes, on which the adsorption of protein could be adjusted through the change of the hydrophobic/ hydrophilic behavior of mixed polymer brushes with temperature in an aqueous environment. Firstly, the comb copolymer, PMOXA-r-GMA was synthesized via cationic ring opening polymerization (CROP) of MOXA followed by its random copolymerization with GMA according to our previous work; ${ }^{28,31,44}$ and poly(glycidyl methacrylate)-block-poly( $N$-isopropyl acrylamide)block-polystyrene (PGMA- $b$-PNIPAM- $b$-PSt) was synthesized by reversible addition-fragmentation chain transfer (RAFT) polymerization of GMA, $N$-isopropyl acrylamide (NIPAM), and styrene (St) step by step. Then the mixed brushes based on PMOXA and PNIPAM- $b$-PSt were fabricated by spin coating the mixture of PMOXA-r-GMA and PGMA- $b$-PNIPAM- $b$-PSt solutions onto silicon or glass substrates followed by an annealing protocol. A strategy to design mixed brushes is shown in Scheme 1. The hydrophilic character of the mixed brush is provided by highly hydrophilic PMOXA, which is end grafted to the surface by using GMA units existing in PMOXA-r-GMA as an anchor. PGMA- $b$-PNIPAM- $b$-PSt was grafted to the surface by using a PGMA block as the anchor, where the PNIPAM block tethered to PGMA anchor is a thermoresponsive polymer chain and serves as a macromolecular actuator to bring the highly hydrophobic PSt block to the surface upon the external temperature change. In PMOXA-r-GMA/PGMA- $b$-PNIPAM- $b$-PSt mixed brushes, the crosslinking of GMA segments next to the surface could strengthen the anchoring to the surface. In an environment where the tethered PNIPAM blocks are swollen (environmental temperature lower than the LCST of PNIPAM), the PSt hydrophobic domain is exposed to the surface. Such a surface has strong interactions with hydrophobic entities. When the PNIPAM block is not swollen (environmental temperature higher than the LCST of PNIPAM), the hydrophobic domain of the brush is hidden inside the hydrophilic PMOXA grafted polymer layer. Therefore, the hydrophobic/hydrophilic behavior of mixed polymer brushes could be tuned by moving the hydrophobic domains up or down with respect to the top surface. Prepared PMOXA- $r$-GMA/PGMA- $b$-PNIPAM- $b$-PSt coatings were characterized by using X-ray photoelectron spectroscopy (XPS), variable angle spectroscopic ellipsometry (VASE), atomic force microscopy (AFM), and static water contact angle (CA) measurements in order to assess their composition, morphology, thickness, and hydrophilicity respectively. The fluorescein isothiocyanatelabeled protein assay and VASE were used for qualitative and quantitative evaluation of the adsorption of protein on mixed brush coatings respectively through varying the temperature.

\section{Experimental}

\section{Materials}

The water used in all experiments was deionized water. $N, N$-Dimethylformamide (DMF, Sinopharm Chemical Reagents, Shanghai, China) was distilled under reduced pressure before

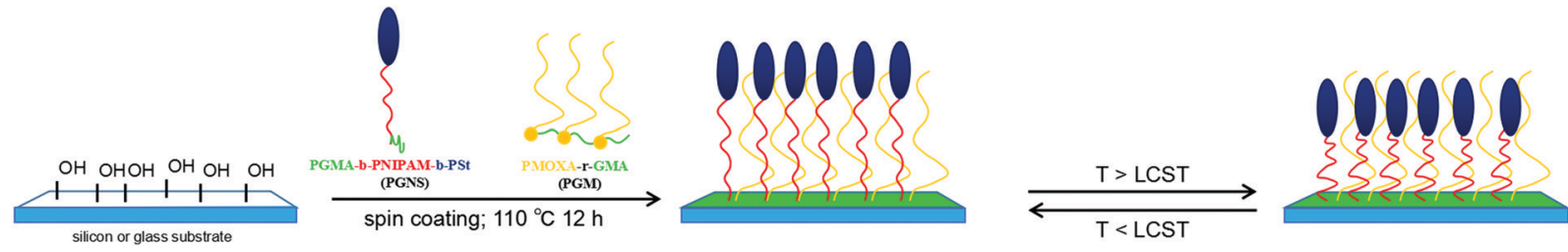

Scheme 1 Strategy of design for PMOXA-r-GMA and PGMA- $b$-PNIPAM- $b$-PSt mixed polymer brushes. 
use. 2,2'-Azobis(2-methylpropionitrile) (AIBN) was recrystallized from methanol. Glycidyl methacrylate (GMA, 97\%, Aladdin, Shanghai, China) and styrene (St, Sinopharm Chemical Reagents, Shanghai, China) were respectively passed through an activated basic alumina column to remove the inhibitor before use. $N$-Isopropyl acrylamide (NIPAM, Aladdin, Shanghai, China) was recrystallized from hexane. $S$-1-Dodecyl- $S^{\prime}$ - $\left(\alpha, \alpha^{\prime}\right.$-dimethyl- $\alpha^{\prime \prime}$ acetic acid) trithiocarbonate (DDMAT) was synthesized according to the previously published procedure. ${ }^{42}$ Fluorescein isothiocyanatelabeled bovine serum albumin (FITC-BSA), fibrinogen (FITC-Fib), and lysozyme (FITC-Lys) were prepared by mixing fluorescein isothiocyanate (FITC, Sigma-Aldrich, USA) with bovine serum albumin (BSA, pI $\sim 4.8, M_{\mathrm{w}} \sim 68 \mathrm{kDa}$, Sigma-Aldrich, USA), fibrinogen (Fib, pI $\sim 5.8, M_{\mathrm{w}} \sim 300 \mathrm{kDa}$, Sigma-Aldrich, USA) and lysozyme (Lys, pI $\sim 10.8, M_{\mathrm{w}} \sim 15 \mathrm{kDa}$, Sigma-Aldrich, USA) respectively at a molar ratio of $1: 1$ in $\mathrm{Na}_{2} \mathrm{CO}_{3}-\mathrm{NaHCO}_{3}$ buffer for $2 \mathrm{~h}$, followed by thorough dialysis in $\mathrm{pH} 7.4$ phosphate-buffered saline (PBS, $10 \mathrm{mM}$ ) for three days. ${ }^{31}$ Glass wafers and microscope glass slides for FITC-immunoassay were bought from Shanghai Jinglun Industry Glass Co. (Shanghai, China). Silicon(111) wafers with a natural oxidized layer were received from Zhejiang Crystal Photoelectric Technology Co. (Zhejiang, China). Other reagents were all obtained from Sinopharm Chemical Reagents (Shanghai, China).

\section{Synthesis of polymers}

Synthesis of PMOXA-r-GMA. PMOXA-r-GMA was synthesized according to our previous work. ${ }^{31}$ By using the same procedure, methacrylate terminated poly(2-methyl-2-oxazoline) (PMOXA-MAA) was synthesized by CROP of MOXA followed by its end-capping with methacrylic acid (MAA), triethylamine (TEA). Then, the PMOXA-MAA underwent random copolymerization with GMA using AIBN as an initiator to obtain the PMOXA-r-GMA comb copolymer. The detailed synthesis procedure is shown in the ESI. $\dagger$ The feed molar ratio of PMOXA-MAA to GMA was maintained to $3: 1$. Relative number average molar mass $\left(M_{\mathrm{n}}\right)$ of resultant PMOXA-MAA and molar ratio of PMOXA-MAA to GMA were calculated by ${ }^{1} \mathrm{H}$ NMR. The synthesized copolymer PMOXA-r-GMA was called PGM for convenience.

Synthesis of PGMA- $b$-PNIPAM- $b$-PSt. At first, a typical procedure of the synthesis of PGMA with a designed $M_{\mathrm{n}}$ of $1000 \mathrm{~g} \mathrm{~mol}^{-1}$ controlled by feed ratio was as follows. GMA $(0.500 \mathrm{~mL}$, $3.70 \mathrm{mmol})$, DDMAT $(0.2009 \mathrm{~g}, 0.500 \mathrm{mmol})$, AIBN (0.0410 g, $0.250 \mathrm{mmol})$, and DMF $(4.0 \mathrm{~mL})$ were introduced into a flamedried Schlenk flask. The reaction mixture was then stirred at $60{ }^{\circ} \mathrm{C}$ under a nitrogen atmosphere for $12 \mathrm{~h}$. After that, the mixture was precipitated in ice-cold ethyl ether, filtered, and dried in vacuum overnight. PGMA- $b$-PNIPAM was synthesized with a designed $M_{\mathrm{n}}$ of PNIPAM block $8000 \mathrm{~g} \mathrm{~mol}^{-1}$ controlled by feed ratio, and a typical procedure was as follows. Produced PGMA (0.500 g, $0.500 \mathrm{mmol})$, NIPAM ( $4.000 \mathrm{~g}, 35.20 \mathrm{mmol})$, AIBN $(0.0410 \mathrm{~g}, 0.250 \mathrm{mmol})$, and DMF $(8.0 \mathrm{~mL})$, were added into a flame-dried Schlenk flask. The reaction mixture was stirred at $60{ }^{\circ} \mathrm{C}$ under a nitrogen atmosphere for $12 \mathrm{~h}$. Afterward, PGMA- $b$ PNIPAM was obtained by precipitating the mixture into ice-cold ethyl ether, then filtering, and drying in vacuum overnight. A series of PGMA- $b$-PNIPAM- $b$-PSt was synthesized with a varied $M_{\mathrm{n}}$ of PSt block. A typical example of PGMA- $b$-PNIPAM- $b$-PSt with a designed $M_{\mathrm{n}}$ of PSt block $1000 \mathrm{~g} \mathrm{~mol}^{-1}$ was as follows. PGMA- $b$-PNIPAM $(4.50 \mathrm{~g}, 0.500 \mathrm{mmol}), \mathrm{St}(0.500 \mathrm{~mL}, 4.30 \mathrm{mmol}), \operatorname{AIBN}(0.0410 \mathrm{~g}$, $0.250 \mathrm{mmol})$, and DMF $(8.0 \mathrm{~mL})$, were added into a flame-dried Schlenk flask. Then the reaction mixture was stirred at $60{ }^{\circ} \mathrm{C}$ under a nitrogen atmosphere for $12 \mathrm{~h}$. After that the mixture was precipitated in ice-cold ethyl ether, filtered, and dried in vacuum overnight to obtain PGMA- $b$-PNIPAM- $b$-PSt. For convenience, PGMA- $b$-PNIPAM was called PGN, triblock copolymers, PGMA- $b$-PNIPAM- $b$-PSt, according to the designed $M_{\mathrm{n}}$ of the PSt block with 1000,6000, 8000 were denoted as PGNS $_{1 \mathrm{k}}$, $\mathrm{PGNS}_{6 \mathrm{k}}$, and PGNS $8 \mathrm{k}$, respectively.

\section{Surface modification}

Silicon/glass wafers were cut into $1 \times 1 \mathrm{~cm}^{2}$ pieces and cleaned by sonication in ethanol ( $15 \mathrm{~min})$, and then in deionized water (15 min). Subsequently, the wafers were cleaned in a piranha solution $\left(7: 3 \mathrm{v} / \mathrm{v}\right.$ mixture of $\mathrm{H}_{2} \mathrm{SO}_{4}(95-98 \%)$ and $\left.\mathrm{H}_{2} \mathrm{O}_{2}(30 \%)\right)$ for $60 \mathrm{~min}$, rinsed extensively with water, ethanol, and then dried under a nitrogen atmosphere before use. Solutions of polymers with PGNS(PGNS ${ }_{1 \mathrm{k}}, \mathrm{PGNS}_{6 \mathrm{k}}$, and $\left.\mathrm{PGNS}_{8 \mathrm{k}}\right) / \mathrm{PGM}$ mass ratio of 10/0 (pure PGNS), 0/10 (pure PGM), 5/5, were prepared by mixing stock chloroform solutions of PGM and PGNS at $10 \mathrm{mg} \mathrm{mL} \mathrm{m}^{-1}$. Spin coating of copolymer solutions $(150 \mu \mathrm{L}$ for $\left.1 \times 1 \mathrm{~cm}^{2}\right)$ was performed on all above substrates for $20 \mathrm{~s}$ at $2000 \mathrm{rpm}$ under vacuum by an EZ4 SPIN COATER (LEBO SCEINCE, China). The coated substrates were subsequently annealed for $12 \mathrm{~h}$ at $110{ }^{\circ} \mathrm{C}$. After annealing, substrates were allowed to cool to room temperature and rinsed with chloroform, alcohol, and deionized water to remove unattached polymer in succession and then dried with nitrogen. To compare with the mixed brush PGNS/PGM coating, a PGN/PGM brush coating was also prepared by using the same annealing protocol as above with a PGN/PGM mass ratio of 10/0 (pure PGN), 5/5 (PGN/PGM), based on the stock chloroform solutions of PGN and PGM at $10 \mathrm{mg} \mathrm{mL}^{-1}$.

\section{Characterizations}

NMR spectroscopy. The ${ }^{1} \mathrm{H}$ NMR spectra of copolymers were recorded using a Bruker DMX-300 instrument at $300 \mathrm{MHz}$. The spectra were acquired at room temperature using a deuterated chloroform solvent and referenced to an internal tetramethylsilane (TMS) standard.

X-ray photoelectron spectroscopy (XPS). The XPS data were collected on a VG ESCALAB MK II X-ray Photoelectron Spectrometer (VG Scientific Instruments, England) with an $\mathrm{Al}\left(\mathrm{K}_{\alpha}\right) \mathrm{X}$-ray source $(1486.6 \mathrm{eV})$. All spectra were calibrated by setting the signal of the aliphatic C signal at $284.7 \mathrm{eV}$ (rather than $285.0 \mathrm{eV}$, given the high proportion of aromatic carbon in the compounds).

Ellipsometry. The dry film thicknesses were measured by using a variable angle spectroscopic ellipsometer (M-2000, Woollam Co., Inc., Lincoln, NE) at room temperature. The measurements were performed in the spectral range of $370-1000 \mathrm{~nm}$ at two different angles of incidence $\left(65^{\circ}\right.$ and $\left.75^{\circ}\right)$. The analysis software, CompleteEASE 4.81, was used to analyze all data. The reported thickness was the average of measurements made from 
at least three spots on the polymer-modified silicon wafer. To fit the ellipsometric data, the optical constants (refractive index, extinction coefficient) of $\mathrm{Si}(n=3.865, k=0.020)$ and $\mathrm{SiO}_{2}$ $(n=1.465, k=0)$ were used to determine the $\mathrm{SiO}_{2}$ layer thickness of the freshly cleaned silicon surfaces. Each polymer layer was represented as a slab of uniform thickness having sharp interfaces and optical properties described by a Cauchy model (refractive index smoothly decaying with wavelength), assuming that the PMOXA-r-GMA and PGMA- $b$-PNIPAM- $b$-PSt layers had refractive indices of 1.45 at $632 \mathrm{~nm}^{45}$

Atomic force microscopy (AFM). The surface topology and surface roughness values of the unmodified and polymer modified silicon surfaces were evaluated on a DI MultimodeV atomic force microscope (AFM) from Veeco Instruments (Mannheim, Germany). The microscope was operated in tapping mode using Si cantilevers with a resonance frequency of $273 \mathrm{kHz}$ and a drive amplitude of $1.30 \mathrm{~V}$ at a scan rate of $0.3 \mathrm{~Hz}$. The AFM images were analyzed and post-processed using NanoScope software (Version 5.12) at room temperature.

Water contact angle measurements (WCA). The static water contact angles (WCA) of bare and modified silicon wafers were measured with a CA system (SL200KB, USA KINO Industry Co., Ltd, USA) at room temperature. The static contact angles were measured using $2 \mu \mathrm{L}$ water droplets that were delivered to the surface using a microliter syringe, and the values were recorded after $1 \mathrm{~s}$. Each sample was measured at three random locations on the modified silicon surface to check its uniformity. Data presented were then averaged by three independent measurements on different locations of the samples, and the results were reported as mean \pm standard deviation (SD).

\section{Switchable properties}

Hydrophilicity. To check the switchable hydrophilic nature of modified surfaces under different temperatures, the WCAs of bare and polymer modified silicon wafers were measured at a temperature of $0{ }^{\circ} \mathrm{C}$ or $38{ }^{\circ} \mathrm{C}$ individually. Firstly, the wafer was placed on a stage of certain temperature loaded with circulating water for $1 \mathrm{~min}$ (an additional thermostatic waterbath was used to control the temperature of circulating water, heating at $38{ }^{\circ} \mathrm{C}$ and ice water mixture at $0{ }^{\circ} \mathrm{C}$ ); and then the WCAs were measured using the same operation conditions as part of the WCA measurements.

Hydrated thickness. To evaluate the thermoresponsive behavior of the polymer modified silicon surfaces, the thickness of the coated substrates dealt with different temperatures was measured. Firstly, the polymer modified substrates were separately immersed in water at $0{ }^{\circ} \mathrm{C}$ or $38^{\circ} \mathrm{C}$ for $2 \mathrm{~h}$ each and then freeze dried for $12 \mathrm{~h}$. After that the thickness of each substrate was measured at three different spots on a polymer modified wafer and the results were reported as mean $\pm \mathrm{SD}$. All the ellipsometric data were fitted using a Cauchy layer model to obtain the thickness of the brushes as described in the Ellipsometry section.

FITC-protein adsorption assay. FITC-BSA, -Fib, and -Lys were chosen as the model protein for the qualitative evaluation of protein adsorption on bare or modified glass wafer surfaces under different temperatures. FITC-BSA was used as an example to describe this procedure. Firstly, uncoated or polymer coated glass wafers were separately immersed in a FITC-BSA solution of PBS (pH 7.4, $10 \mathrm{mM} ; 1 \mathrm{mg} \mathrm{mL}{ }^{-1}$ ) at $0{ }^{\circ} \mathrm{C}$ and $38{ }^{\circ} \mathrm{C}$ and placed in a darkroom for $2 \mathrm{~h}$. After that the respective wafers were washed with PBS and deionized water at $0{ }^{\circ} \mathrm{C}$ or $38{ }^{\circ} \mathrm{C}$ three times, respectively, to remove unbound proteins, followed by drying under a nitrogen atmosphere. The process of the adsorption of FITC-Fib and -Lys on bare or modified glass wafer surfaces under $0{ }^{\circ} \mathrm{C}$ or $38{ }^{\circ} \mathrm{C}$ is the same as FITC-BSA. The fluorescence images of the FITC-BSA, -Fib, and -Lys adsorbed samples were examined using an optical microscope, Olympus BX81 (Olympus, Japan) equipped with a halogen lamp, filter U-MNG2 $\left(\lambda_{\text {exit }}=470-\right.$ $490 \mathrm{~nm}, \lambda_{\text {emit }}>510 \mathrm{~nm}$ ) and camera type DP72. The color intensity was measured using Image J software, and an average value was calculated. The relative adhesion amount of protein was determined qualitatively based on the color intensity of the fluorescence images.

Quantitative analysis of protein adsorption. In this study, the quantitative analysis of protein (BSA, Fib and Lys) adsorption on polymer brushes at $0{ }^{\circ} \mathrm{C}$ and $38{ }^{\circ} \mathrm{C}$ was performed by measuring ellipsometry thickness of bare and polymer modified silicon wafers before and after the protein (BSA, Fib and Lys) adsorption. The dry thicknesses of bare or modified silicon substrates were measured at room temperature firstly, then bare or polymer modified wafers were immersed in protein solution of PBS (pH 7.4, $10 \mathrm{mM} ; 1 \mathrm{mg} \mathrm{mL}{ }^{-1}$ ) at $0{ }^{\circ} \mathrm{C}$ for $2 \mathrm{~h}$, washed with water at $0{ }^{\circ} \mathrm{C} 3$ times, dried with nitrogen and then the thickness after protein adsorption at $0{ }^{\circ} \mathrm{C}$ was measured at room temperature. The measurement process of the ellipsometry thickness of bare and modified silicon wafers after protein adsorption at $38{ }^{\circ} \mathrm{C}$ was the same as the procedure mentioned above, only the temperature of the protein solution and rinsing water was maintained at $38{ }^{\circ} \mathrm{C}$. The adsorbed mass $\left(\Delta m, \mathrm{ng} \mathrm{cm}^{-2}\right)$ of protein on the bare and polymer modified silicon wafers was calculated using the following equation ${ }^{46-49}$

$$
\Delta m=\rho \times \Delta h \times S
$$

where $S$ is the cross-sectional area of the silicon wafers, $\rho$ is the density of the proteins (the density of BSA, Fib, Lys are assumed to be $\left.1 \mathrm{~g} \mathrm{~cm}^{-3}\right),{ }^{47}$ and $\Delta h$ is the difference of thickness before and after the protein adsorption.

\section{Results and discussion}

\section{Preparation of polymer}

PMOXA-r-GMA (PGM) was synthesized via CROP of MOXA followed by its random copolymerization with GMA according to our previous work. ${ }^{31}$ The ${ }^{1} \mathrm{H}$ NMR result (Fig. S1 in the ESI $\dagger$ ) showed that $M_{\mathrm{n}}$ of PMOXA chain on PGM is about $4900 \mathrm{~g} \mathrm{~mol}^{-1}$, and contour chain length of PMOXA side chains on PGM is about $20.1 \mathrm{~nm}$ (Table $\mathrm{S} 1$ in the ESI $\dagger$ ).

PGMA- $b$-PNIPAM- $b$-PSt with a different design $M_{\mathrm{n}}$ of PSt block $\left(\mathrm{PGNS}_{1 \mathrm{k}}, \mathrm{PGNS}_{6 \mathrm{k}}\right.$ and $\mathrm{PGNS}_{8 \mathrm{k}}$ ) was synthesized by RAFT polymerization of St with the PGMA- $b$-PNIPAM-macro-RAFT agent (PGN). As shown in Fig. 1a, the resonance peaks a $(\delta \sim 2.6 \mathrm{ppm}, 2.8 \mathrm{ppm})$ 
(a)
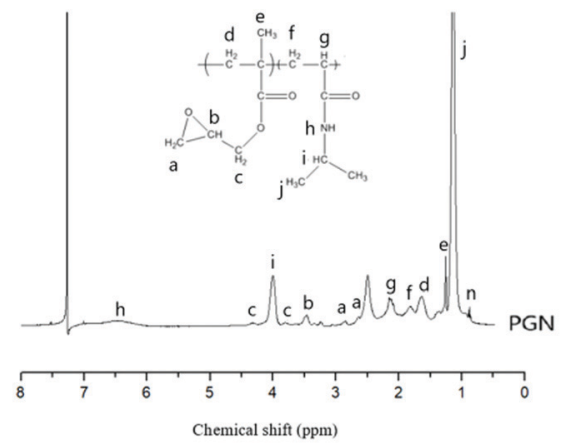

(b)

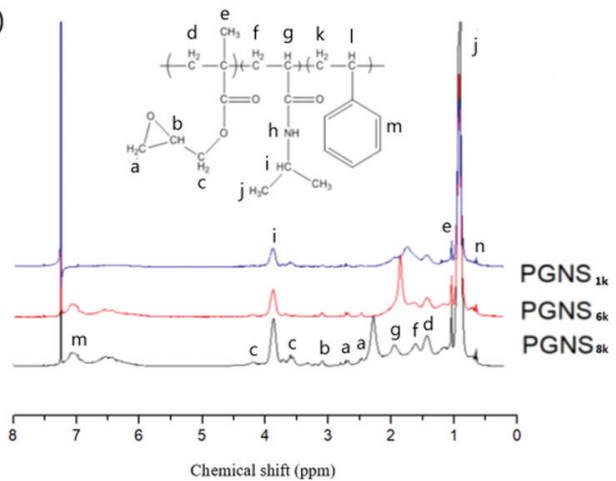

Fig. $1{ }^{1} \mathrm{H}$ NMR spectra of (a) PGN, and (b) PGNS ${ }_{1 \mathrm{k}}, \mathrm{PGNS}_{6 \mathrm{k}}$, and PGNS $\mathrm{Pk}_{8 \mathrm{k}}$ in $\mathrm{CDCl}_{3}$.

and $\mathrm{b}(\delta \sim 3.5 \mathrm{ppm})$ were assigned to the protons of methylene and methine of the GMA epoxide group individually, while the peak c ( $\delta \sim 3.8 \mathrm{ppm}, 4.3 \mathrm{ppm}$ ) was assigned to the methylene connected to the epoxide groups. The signals of proton from the isopropyl group of NIPAM were detected at the resonance peaks of $\mathrm{i}(\delta \sim 4.0 \mathrm{ppm})$, and $\mathrm{j}(\delta \sim 1.2 \mathrm{ppm})$. These significant proton signals confirm the successful synthesis of PGN. The $M_{\mathrm{n}}$ of the PGMA block in PGN is about $770 \mathrm{~g} \mathrm{~mol}^{-1}$, determined by calculating relative peak areas corresponding to the peak $\mathrm{n}$ from DDMAT $(\delta \sim 0.8-0.9 \mathrm{ppm})$ and peak c ( $\delta \sim 3.8 \mathrm{ppm}, 4.3 \mathrm{ppm})$; the $M_{\mathrm{n}}$ of PNIPAM block in PGN is about $7900 \mathrm{~g} \mathrm{~mol}^{-1}$ determined by calculating the relative peak areas corresponding to the peak $\mathrm{n}$ from DDMAT RAFT agent's end $\mathrm{CH}_{3}(\delta \sim 0.8-0.9 \mathrm{ppm})$ and peak i $(\delta \sim 4.0 \mathrm{ppm})$. The theoretical chain length of the PNIPAM block is $20.3 \mathrm{~nm}$ (Table S1 in the ESI†). Fig. $1 \mathrm{~b}$ shows the ${ }^{1} \mathrm{H}$ NMR of PGNS with varying $M_{\mathrm{n}}$ of the PSt block. In addition to all other corresponding peaks of PGN, a new significant peak was detected at 6.7-7.2 ppm, assigned to the phenyl group of styrene, confirming the successful synthesis of PGNS. The intensity of this peak $(\delta \sim 6.7-7.2 \mathrm{ppm})$ increases by increasing the designed $M_{\mathrm{n}}$ of the PSt block from $1 \mathrm{k}$ to $8 \mathrm{k}$ respectively. The $M_{\mathrm{n}}$ of the PSt block of PGNS ${ }_{1 \mathrm{k}}, \mathrm{PGNS}_{6 \mathrm{k}}$ and $\mathrm{PGNS}_{8 \mathrm{k}}$ are 1232, 5897, and $7925 \mathrm{~g} \mathrm{~mol}^{-1}$ respectively, determined by the relative peak areas of the DDMAT's end methyl peak ( $\delta \sim 0.8-0.9 \mathrm{ppm})$ and phenyl group signal of styrene $(\delta \sim 6.7-7.2 \mathrm{ppm})$, close to the designed $M_{\mathrm{n}}$ of PSt block. The contour chain length of $\mathrm{PGNS}_{1 \mathrm{k}}, \mathrm{PGNS}_{6 \mathrm{k}}$ and $\mathrm{PGNS}_{8 \mathrm{k}}$ are 23.2, 37.5 and $43.2 \mathrm{~nm}$, respectively, while the contour chain lengths of the PSt block of PGNS 1 k PGNS $_{6 \mathrm{k}}$ and PGNS $_{8 \mathrm{k}}$ are 2.9, 17.2and $22.9 \mathrm{~nm}$ respectively. The detailed chain length calculation is shown in Table S1 of the ESI. $\dagger$

\section{Characterization of polymer modified surfaces}

The XPS measurements were used to determine the surface composition of the polymer coatings formed on the silicon wafers. The XPS wide scan spectra and high-resolution C1s of bare, PGN, PGM, PGNS 1 , PGNS $_{6 \mathrm{k}}$, PGNS $_{8 \mathrm{k}}$, PGN/PGM, PGNS $1 \mathrm{k} /$ PGM, PGNS ${ }_{6 \mathrm{~K}} / \mathrm{PGM}$, and $\mathrm{PGNS}_{8 \mathrm{k}} / \mathrm{PGM}$ modified silicon wafers are shown in Fig. S3 and S4 of the ESI, $\dagger$ and the corresponding atomic percentage of elements on bare and modified substrates is listed in Table 1. Compared to the bare silicon surface, clear changes in carbon (C1s, $287 \mathrm{eV})$, nitrogen (N1s, $400.5 \mathrm{eV}$ ), oxygen (O1s, $533 \mathrm{eV}$ ), and silicon (154 eV for Si2s and $103 \mathrm{eV}$ for Si2p) signals were observed in modified silicon surfaces. For instance, in the PGM modified substrate, increments in carbon (C1s, $287 \mathrm{eV}$ ), nitrogen (N1s, $400.5 \mathrm{eV}$ ), and oxygen signals (O1s, $533 \mathrm{eV}$ ), with corresponding decreases in silicon (154 eV for Si2s and $103 \mathrm{eV}$ for Si2p) signals confirmed the successful immobilization of PGM on the substrate as reported previously. ${ }^{31}$ The intensities of the carbon $(\mathrm{C} 1 \mathrm{~s}, 287 \mathrm{eV})$ signal increase with increasing the

Table 1 The atomic percentage of elements on the bare and polymer modified surface based on XPS, with corresponding dry thickness, and water contact angles

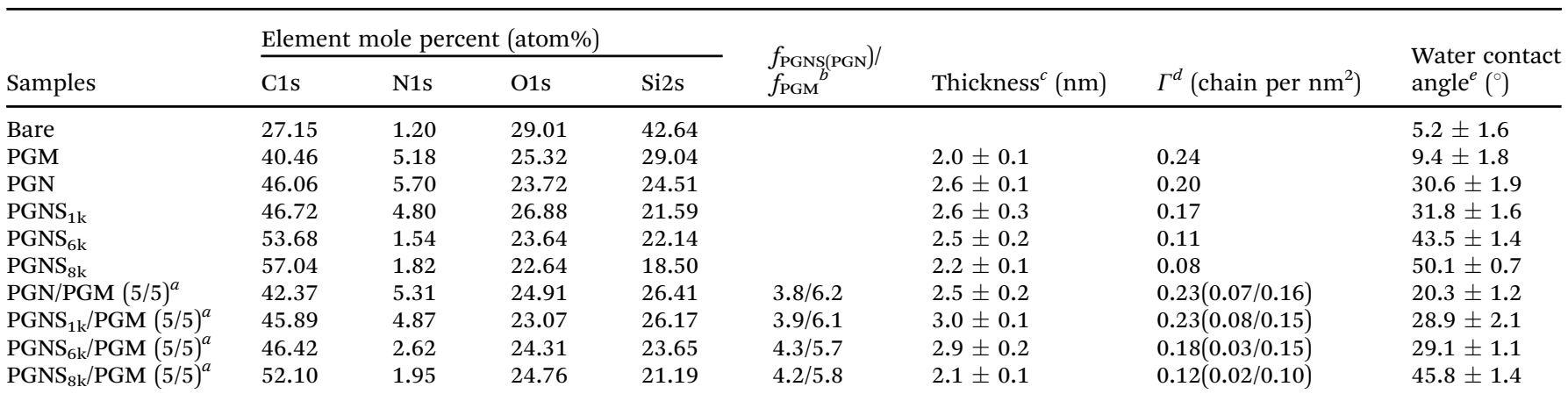

${ }^{a}$ Feed mass ratio of PGNS (or PGN) to PGM in mixed polymer brushes. ${ }^{b}$ Mass ratio of PGNS (or PGN) to PGM in mixed polymer brushes calculated according to eqn (S4) and (S5), ESI. ${ }^{c}$ Data obtained in dry film and expressed as mean $\pm \operatorname{SD}(n=3) .{ }^{d}$ The grafting density $\Gamma$ of polymer brushes expressed by the chain number per square nanometer calculated according to eqn (S6)-(S13) (ESI). The grafting density ratio of PGNS (or PGN) to PGM in mixed polymer brushes are given in parentheses calculated according to eqn (S9)-(S12) (ESI). ${ }^{e}$ Data measured at room temperature and expressed as mean $\pm \mathrm{SD}(n=3)$. 
molar mass of the PSt block from PGN to $\mathrm{PGNS}_{8 \mathrm{k}}$ respectively. For the mixed polymer brushes of PGN/PGM, PGNS $_{1 \mathrm{k}} / \mathrm{PGM}$, $\mathrm{PGNS}_{6 \mathrm{k}} / \mathrm{PGM}$, and $\mathrm{PGNS}_{8 \mathrm{k}} / \mathrm{PGM}$ (mass ratio of PGN (PGNS) and PGM was 5/5, the details for determination of the ratio of PGNS and PGM are described in the ESI $\dagger$ ), the intensity of the carbon (C1s, $287 \mathrm{eV}$ ) and nitrogen (N1s, $400.5 \mathrm{eV}$ ) signal between the intensity of pure PGM and pure PGN or corresponding PGNS modified silicon wafers, suggested the presence of both polymers on the silicon wafer. The area of $\mathrm{O}=\mathrm{C}-\mathrm{N}$ peak $(288.6 \mathrm{eV})$ from the amide bond of the PNIPAM block or PMOXA part (Fig. S4 of the ESI $\dagger$ ) decreased with the increment of the PSt block from PGN/PGM to $\mathrm{PGNS}_{8 \mathrm{k}} / \mathrm{PGM}$ (Table S2 of the ESI $\dagger$ ), further indicating the presence of both PGM and PGN(PGNS) copolymers on the PGN(PGNS)/PGM modified surface.

The relative mass fraction of PGN, PGM, and PGNS $\left(f_{\mathrm{PGN}}\right.$, $\left.f_{\mathrm{PGM}}, f_{\mathrm{PGNS}}\right)$ in the mixed polymer brushes of PGN/PGM, $\mathrm{PGNS}_{1 \mathrm{k}} / \mathrm{PGM}, \mathrm{PGNS}_{6 \mathrm{k}} / \mathrm{PGM}$, and $\mathrm{PGNS}_{8 \mathrm{k}} / \mathrm{PGM}$ were calculated by using eqn (S4) and (S5) in the ESI $\dagger$ based on XPS results, and the results are presented in Table 1 . The results demonstrated that the resultant mass fraction of PGN, PGM, and PGNS on the mixed polymer brush modified surfaces are close to the feed mass ratio (5/5) (resultant mass fraction based on the XPS results for other feed mass ratios of $\mathrm{PGNS}_{6 \mathrm{k}} / \mathrm{PGM}$ is described in Table S2, ESI $\dagger$ ), implying that the surface composition could be controlled by the concentration ratio of polymers in the mixed polymer solutions which were used to fabricate mixed polymer brush coatings.

Furthermore, the dry thickness of polymer modified surfaces were determined at room temperature and the results are given in Table 1 . The results showed that the dry thickness of all the polymer modified surfaces are in the range of $2-3 \mathrm{~nm}$ and it is higher than that of the bare silicon wafer $(\sim 0 \mathrm{~nm})$. The grafting density of polymers on these samples could be estimated by using eqn (S6)-(S13) of the ESI $\dagger$ based on ellipsometry thickness. As shown in Table 1, the grafting density of the PGM is 0.24 chain per $n m^{2}$. From PGN to $\mathrm{PGNS}_{8 \mathrm{k}}$ the grafting density decreased from 0.20 chain per $\mathrm{nm}^{2}$ to 0.08 chain per $\mathrm{nm}^{2}$, suggesting that the polymer brushes with the larger PSt block have the lowest graft density on the substrate. From PGN/PGM to $\mathrm{PGNS}_{8 \mathrm{k}} / \mathrm{PGM}$ the grafting density decrease from 0.23 to 0.12 chain per $\mathrm{nm}^{2}$, the grafting density of PGM also decrease from 0.16 to 0.10 chain per $\mathrm{nm}^{2}$ with an increment of PSt block's molar mass, because of the steric hindrance of the PSt block.

The WCA of bare and polymer modified silicon wafers were also measured at room temperature and the results are depicted in Table 1 . The value of WCA on bare silicon wafer is $5.2^{\circ}$ representing its hydrophilic nature after dealing with piranha solution. The value of the PGM modified silicon wafer is $9.4^{\circ}$, confirming the hydrophilic properties of PMOXA chains as reported previously. ${ }^{31}$ While for PGN modified surfaces, the WCA increased sharply to $30.6^{\circ}$, because PNIPAM is more hydrophobic than PMOXA at room temperature. ${ }^{39}$ The WCAs of the PGNS modified wafters are higher than the PGN modified wafers, due to the presence of a PSt block with hydrophobic nature, and the WCA increased from $31.8^{\circ}, 43.5^{\circ}$ to $50.1^{\circ}$ with increasing the molar mass of the PSt block from PGNS $_{1 \mathrm{k}}$,
$\mathrm{PGNS}_{6 \mathrm{k}}$, to $\mathrm{PGNS}_{8 \mathrm{k}}$ respectively. For the modified silicon wafer with PGN/PGM brushes, WCA $\left(20.3^{\circ}\right)$ was observed to be in between that of the pure PGM and pure PGN modified wafer. For modified silicon wafers with $\mathrm{PGNS}_{1 \mathrm{k}} / \mathrm{PGM}, \mathrm{PGNS}_{6 \mathrm{k}} / \mathrm{PGM}$, and $\mathrm{PGNS}_{8 \mathrm{k}} / \mathrm{PGM}$, WCA values decreased compared with their corresponding pure PGNS brushes, and WCA values increased from $28.9^{\circ}, 29.1^{\circ}$ to $45.8^{\circ}$ with increasing the molar mass of PSt block from $\mathrm{PGNS}_{1 \mathrm{k}}, \mathrm{PGNS}_{6 \mathrm{k}}$, to $\mathrm{PGNS}_{8 \mathrm{k}}$ respectively. Taking into account of XPS, thickness, and WCA data, it is confirmed that a silicon substrate could be modified successfully by PGM, PGN, PGNS and mixed polymer brushes of PGN/PGM, and PGNS/PGM with good surface coverage and controlled surface composition using an annealing protocol.

To further examine the grafting of polymers on the silicon substrates, surface morphology was investigated by using AFM with tapping mode and the results are illustrated in Fig. 2. The arithmetical mean deviation of the roughness profile https:// www.baidu.com/javascript; $\left(R_{\mathrm{a}}\right)$ value increased from $0.294 \mathrm{~nm}$ of bare silicon to $5.05 \mathrm{~nm}$ of modified silicon wafers. The higher roughness values of the polymer modified surfaces comparing with bare substrate clearly indicated the successfully grafting of the polymers on the silicon surfaces. Compared with PGN (1.86 nm) or PGN/PGM (2.54 nm), the Ra of PGNS or PGNS/PGM increased with increasing the molar mass of PSt block, implying that the hydrophobic segregated PSt domain would reach to the top exterior boundary of the brush with increasing the molar mass of the PSt block. These results are consistent with the WCA data obtained at room temperature, in which WCA values increased with increasing the molar mass of the PSt block from PGNS $_{1 \mathrm{k}}$ to PGNS $_{8 \mathrm{k}}$ in either the PGNS brush or PGNS/PGM mixed brushes coating.

\section{Switching of hydrophilic/hydrophobic properties}

The WCA measurement is the basic method to investigate the surface hydrophilicity that is commonly used to examine the antifouling properties of the material surfaces. Fig. 3a shows polymer modified silicon surfaces at $0{ }^{\circ} \mathrm{C}$ and $38{ }^{\circ} \mathrm{C}$, respectively. The WCA of PGM modified silicon surfaces exhibited negligible transition from $0{ }^{\circ} \mathrm{C}$ to $38{ }^{\circ} \mathrm{C}$, anticipating the temperature independent nature of PMOXA. Also, very low WCA values (around $10^{\circ}$ both at $0{ }^{\circ} \mathrm{C}$ and $38{ }^{\circ} \mathrm{C}$ ) represent the strong hydrophilic property of PMOXA. The WCA of PGN modified silicon surfaces jumped from $20^{\circ}$ to $40^{\circ}$ by increasing the temperature from $0{ }^{\circ} \mathrm{C}$ to $38{ }^{\circ} \mathrm{C}$. The difference in WCA $(\triangle \mathrm{WCA})$ between $0{ }^{\circ} \mathrm{C}$ and $38{ }^{\circ} \mathrm{C}$ represents the thermoresponsive behavior of PNIPAM. Below the LCST of PNIPAM $\left(0{ }^{\circ} \mathrm{C}\right)$, PNIPAM chains would swell and adsorb water, causing the lower WCA of the PGN modified surface; while above the LCST of PNIPAM $\left(38^{\circ} \mathrm{C}\right)$, the PNIPAM chains collapse and undergo water repellent properties, thus an increment in the WCA was observed in the PGN modified surface. ${ }^{50-52}$ As compared to the PGN modified surface, increment in the WCA was observed for the PGNS modified surface both at $0{ }^{\circ} \mathrm{C}$ and $38{ }^{\circ} \mathrm{C}$, and the values of WCA increased with increasing the molar mass of the PSt block from $\mathrm{PGNS}_{1 \mathrm{k}}$ to $\mathrm{PGNS}_{8 \mathrm{k}}$. Moreover, $\triangle \mathrm{WCA}$ from $0{ }^{\circ} \mathrm{C}$ to $38{ }^{\circ} \mathrm{C}$ is less than $5^{\circ}$. These results indicated that the addition of a PSt 

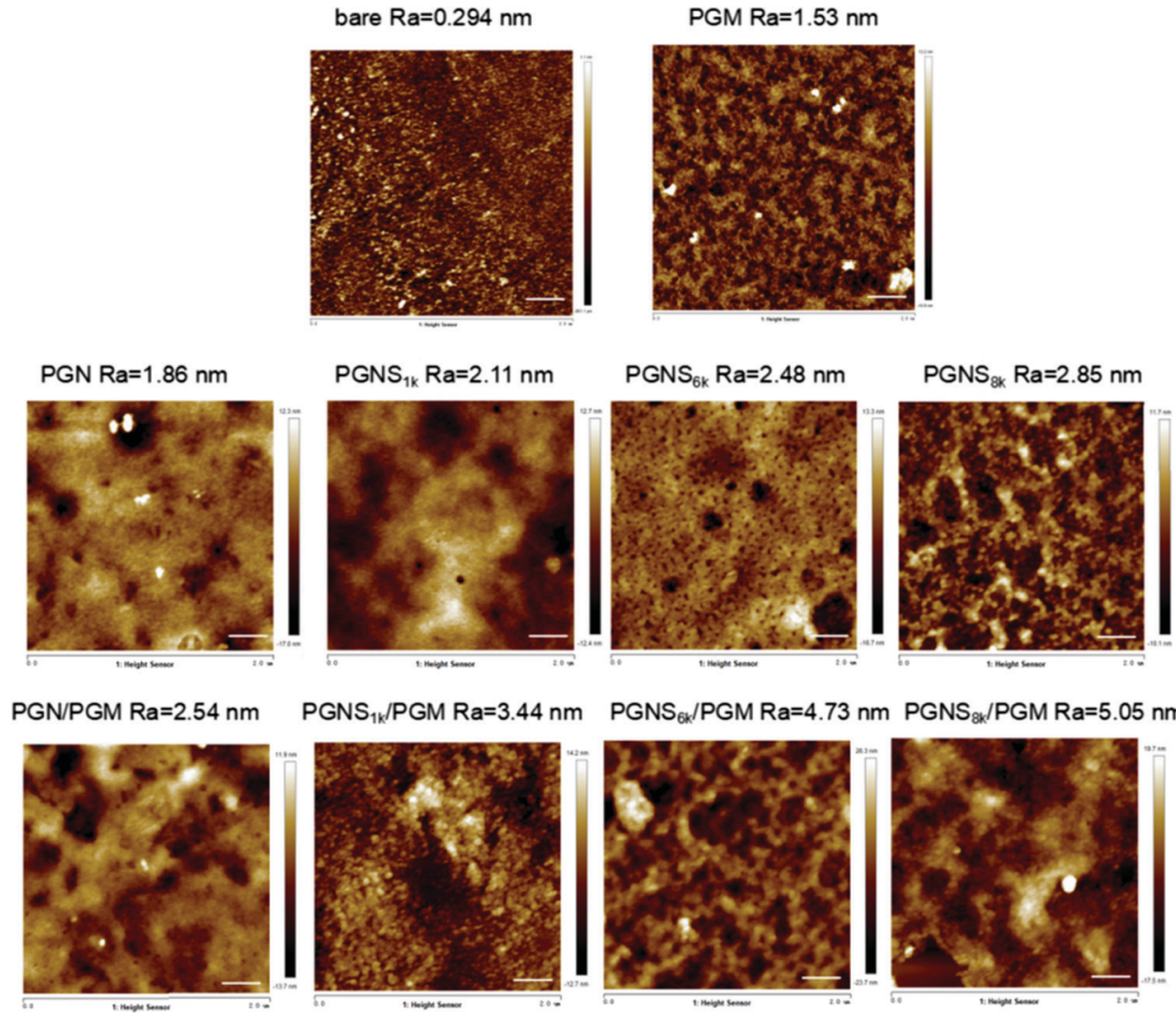

Fig. 2 AFM images of bare, PGN, PGM, PGNS ${ }_{1 k}, P G N S_{6 k}, P G N S_{8 k}$ and PGNS ${ }_{1 k} / P G M, P G N S_{6 k} / P G M, P G N S_{8 k} / P G M$ modified silicon wafer. The scan size was $2 \times 2 \mu \mathrm{m}^{2}$, scale bar was $200 \mathrm{~nm}$, and the vertical scale was $20 \mathrm{~nm}$.

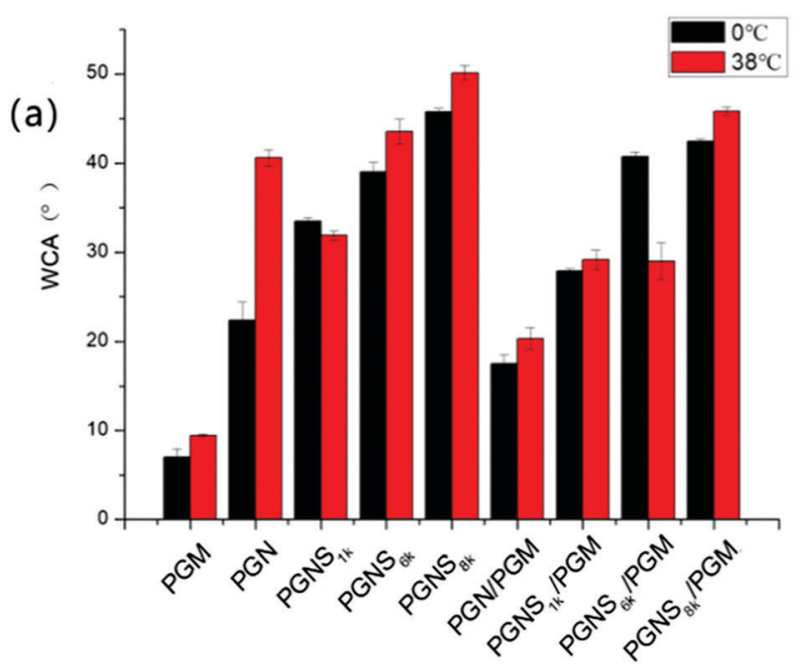

(b)

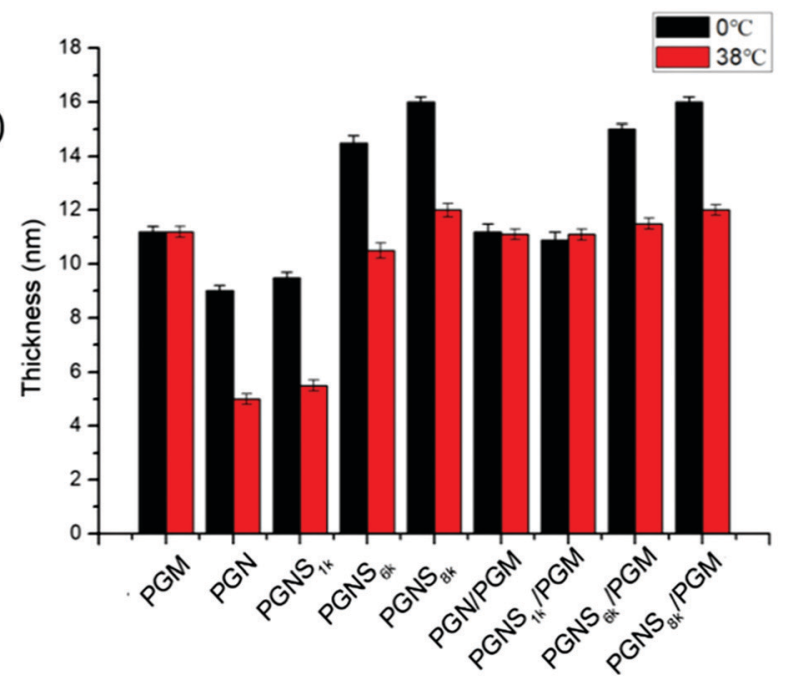

Fig. 3 WCA value (a) and hydrated thickness (b) at $0{ }^{\circ} \mathrm{C}$ and $38{ }^{\circ} \mathrm{C}$ for PGN, PGM, PGNS ${ }_{1 k}, P G N S_{6 k}, P G N S_{8 k}$ and PGN/PGM, PGNS $1 k / P G M, P G N S_{6 k} / P G M$, $\mathrm{PGNS}_{8 \mathrm{k}} / \mathrm{PGM}$ modified silicon wafer. Data are expressed as mean $\pm \mathrm{SD}(n=3)$.

block in the PGNS modified surface could improve the hydrophobicity of the surface both at $0{ }^{\circ} \mathrm{C}$ and $38{ }^{\circ} \mathrm{C}$. For the mixed polymer brushes of PGN/PGM, WCA varies from $16^{\circ}$ to $22^{\circ}$ by increasing the temperature from $0{ }^{\circ} \mathrm{C}$ and $38{ }^{\circ} \mathrm{C}$, representing its thermoresponsive abilities but the extent of responsiveness is lower than the pure PGN modified surface due to the presence of
PMOXA side chains in PGM. Where the mixed polymer brushes of PGNS/PGM are concerned, a very interesting behavior of WCA was observed. For instance, the WCA of $\mathrm{PGNS}_{1 \mathrm{k}} / \mathrm{PGM}$ remains approximately the same both at $0{ }^{\circ} \mathrm{C}$ and $38{ }^{\circ} \mathrm{C}$ and its value is about $28^{\circ}$. For $\mathrm{PGNS}_{6 \mathrm{k}} / \mathrm{PGM}$, the WCA increased to $43^{\circ}$ at $0{ }^{\circ} \mathrm{C}$ and reduced to $30^{\circ}$ at $38{ }^{\circ} \mathrm{C}$ suggesting its shifting from a 
hydrophobic to hydrophilic nature below and above the LCST of PNIPAM respectively. To $\mathrm{PGNS}_{8 \mathrm{k}} / \mathrm{PGM}$, very little difference in WCA $\left(42^{\circ}\right.$ at $0{ }^{\circ} \mathrm{C}, 44^{\circ}$ at $\left.38^{\circ} \mathrm{C}\right)$ was observed as the temperature was moved from $0{ }^{\circ} \mathrm{C}$ to $38{ }^{\circ} \mathrm{C}$.

To further evaluate the switchable properties of the polymer modified surfaces, the hydrated thickness was measured after wafers were immersed in the solution of $0{ }^{\circ} \mathrm{C}$ and $38{ }^{\circ} \mathrm{C}$, respectively, and they were subsequently lyophilized, and the results are depicted in Fig. $3 \mathrm{~b}$. It was observed that the average hydrated thickness of PGM was not changed by varying the temperature from $0{ }^{\circ} \mathrm{C}$ to $38{ }^{\circ} \mathrm{C}$. In contrast, the hydrated thickness of PGN varied significantly with increasing the temperature from $0{ }^{\circ} \mathrm{C}$ to $38{ }^{\circ} \mathrm{C}$. For instance, at $0{ }^{\circ} \mathrm{C}$, the average hydrated thickness of PGN was $9 \mathrm{~nm}$ which was reduced to $4 \mathrm{~nm}$ by increasing the temperature to $38{ }^{\circ} \mathrm{C}$. The difference in thickness is due mainly to swelling of PNIPAM chains below the LCST $\left(0{ }^{\circ} \mathrm{C}\right)$ and deswelling above the LCST $\left(38^{\circ} \mathrm{C}\right)$. For PGNS modified surfaces, the average hydrated thickness increased both at $0{ }^{\circ} \mathrm{C}$ and $38{ }^{\circ} \mathrm{C}$ respectively by increasing the molar mass of the PSt block in PGNS from PGNS $1 \mathrm{k}$ to PGNS $_{8 \mathrm{k}}$. Moreover, regardless of the molar mass of PSt, the average hydrated thickness of PGNS with the same PSt block was higher at $0{ }^{\circ} \mathrm{C}$ and lower at $38{ }^{\circ} \mathrm{C}$. This might be due to the swelling of PNIPAM chains in PGNS at $0{ }^{\circ} \mathrm{C}$ and deswelling of PNIPAM chains in PGNS at $38{ }^{\circ} \mathrm{C}$ respectively. For the mixed polymer brushes of PGN/PGM, the hydrated thickness increased as compared to the pure PGN brush both at $0{ }^{\circ} \mathrm{C}$ and $38{ }^{\circ} \mathrm{C}$, and remained almost the same as that of the PGM brush. The hydrated thickness of the $\mathrm{PGNS}_{1 \mathrm{k}} / \mathrm{PGM}$ coating remains constant both at $0{ }^{\circ} \mathrm{C}$ and $38{ }^{\circ} \mathrm{C}$, and also the value of hydrated thickness was almost the same as that of PGN/PGM, illustrating little contribution of the PSt block with low molar mass. For $\mathrm{PGNS}_{6 \mathrm{k}} / \mathrm{PGM}$, and $\mathrm{PGNS}_{8 \mathrm{k}} / \mathrm{PGM}$ modified silicon wafers, the hydrated thickness increases sharply to $15 \mathrm{~nm}$ and $16.5 \mathrm{~nm}$ respectively at $0{ }^{\circ} \mathrm{C}$, while the values of hydrated thickness decrease at $38{ }^{\circ} \mathrm{C}$ both for $\mathrm{PGNS}_{6 \mathrm{k}} / \mathrm{PGM}$ and $\mathrm{PGNS}_{8 \mathrm{k}} / \mathrm{PGM}$. The pure PGM brush modified silicon wafer remains hydrophilic irrespective to the change of temperature due to the presence of PMOXA chains in PGM. On the other hand, the pure PGN brush shows swelling when $T<$ LCST of PNIPAM and obtains a hydrophilic nature; by increasing the temperature ( $T>$ LCST), PNIPAM chains collapse and show strong hydrophobic behavior, representing the dominant role of PNIPAM in PGN. After being modified with PGNS, the substrates displayed a more hydrophobic nature compared with pure PGN modified substrates, and this hydrophobic property varied a little with the temperature and increased with increasing the molar mass of the PSt block (Fig. 3a); meanwhile the increment in brush thickness with the molar mass of the PSt block and the switchable behavior in thickness upon temperature change were observed (Fig. 3b). These results suggested that the hydrophobicity of PGNS modified substrates was determined by the PSt block, and the switchable behavior in thickness was determined by the PNIPAM block. Although the contour chain length of PMOXA $(20.1 \mathrm{~nm})$ in PGM is similar to that of PNIPAM $(20.3 \mathrm{~nm})$ in PGN (Table S1 of the $\mathrm{ESI} \dagger)$, the hydrated thickness of the PGM modified substrate is higher than that of the PGN modified substrate at both $0{ }^{\circ} \mathrm{C}$ and $38{ }^{\circ} \mathrm{C}$ (Fig. 3b), and the PGM modified substrate is more hydrophilic than the PGN modified substrate at both $0{ }^{\circ} \mathrm{C}$ and $38{ }^{\circ} \mathrm{C}$ (Fig. 3a). Therefore, for PGN/PGM mixed polymer brushes coating, the hydrated thickness and hydrophilicity are determined by the PGM part owing to its position in the mixed brush exterior, and is kept almost the same at both $0{ }^{\circ} \mathrm{C}$ and $38{ }^{\circ} \mathrm{C}$ as shown in Scheme 2. For the PGNS/PGM mixed polymer brushes coating, though the total contour chain length of PNIPAM and PSt block in all PGNS is longer than that of PMOXA in the PGM part $(23.2 \mathrm{~nm}$ for PGNS $_{1 \mathrm{k}}, 37.5 \mathrm{~nm}$ for $\mathrm{PGNS}_{6 \mathrm{k}}$, and $43.2 \mathrm{~nm}$ for PGNS $6 \mathrm{k}$, Table S1 in the ESI $\dagger$ ), the hydrophilicity/hydrophobicity of modified substrates are different. For PGNS ${ }_{1 \mathrm{k}} / \mathrm{PGM}$ mixed brushes, the total contour chain length of PNIPAM and PSt block in PGNS ${ }_{1 \mathrm{k}}$ is a little longer than that of PMOXA in PGM, but the hydrated thickness of pure PGM is much higher than pure $\mathrm{PGNS}_{1 \mathrm{k}}$ at both $0{ }^{\circ} \mathrm{C}$ and $38{ }^{\circ} \mathrm{C}$, leading to the dominant role of PGM in mixed brushes; hence the hydrated thickness and hydrophilicity are determined by the PGM part, and kept almost the same at both $0{ }^{\circ} \mathrm{C}$ and $38{ }^{\circ} \mathrm{C}$ as shown in Scheme 2. For $\mathrm{PGNS}_{6 \mathrm{k}} / \mathrm{PGM}$ mixed brushes, the total contour chain length of PNIPAM and the PSt block in PGNS $_{6 \mathrm{k}}$ increased greatly with increasing the molar mass of the PSt block, meanwhile, the hydrated thickness of pure $\mathrm{PGNS}_{6 \mathrm{k}}$ is much higher than that of PGM at $0{ }^{\circ} \mathrm{C}$, and lower than that of PGM at $38{ }^{\circ} \mathrm{C}$ (Fig. 3b), suggesting that PGNS $_{6 \mathrm{k}}$ would dominate the modified substrate at $0{ }^{\circ} \mathrm{C}$ representing the hydrophobicity of the PSt block, and PGM would dominate the modified substrate at $38{ }^{\circ} \mathrm{C}$ representing hydrophilicity (Fig. 3a) as shown in Scheme 2. By further increases the molar mass of PSt in the mixed polymer brushes $\left(\mathrm{PGNS}_{8 \mathrm{k}} / \mathrm{PGM}\right)$, the contour chain length of the PSt block increased greatly, and the total contour chain length of PNIPAM and the PSt block in PGNS $_{8 \mathrm{k}}$ is much longer than that of PMOXA in PGM; moreover, both the hydrated thickness of

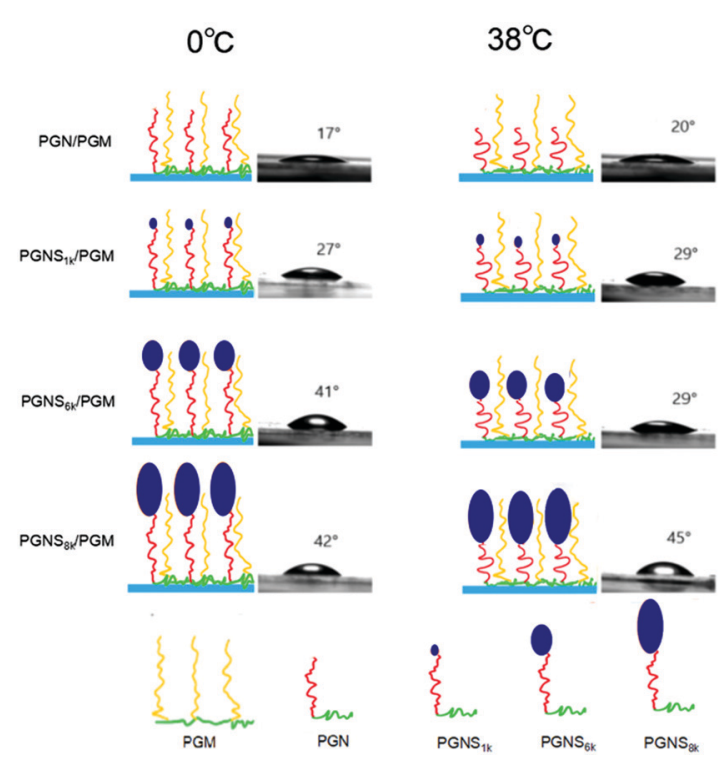

Scheme 2 Illustration of the thermoresponsive behavior of PGN/PGM, $\mathrm{PGNS}_{1 \mathrm{k}} / \mathrm{PGM}, \mathrm{PGNS}_{6 \mathrm{k}} / \mathrm{PGM}$, and $\mathrm{PGNS}_{8 \mathrm{k}} / \mathrm{PGM}$ mixed polymer brushes coating. 
pure $\mathrm{PGNS}_{8 \mathrm{k}}$ are higher than PGM at $0{ }^{\circ} \mathrm{C}$ and $38{ }^{\circ} \mathrm{C}$ (Fig. 3b) due to the high molar mass of the PSt block, implying that $\mathrm{PGNS}_{8 \mathrm{k}}$ would control the wettability of the $\mathrm{PGNS}_{8 \mathrm{k}} / \mathrm{PGM}$ modified surface; consequently the $\mathrm{PGNS}_{8 \mathrm{k}} / \mathrm{PGM}$ modified substrate remains hydrophobic both at $0{ }^{\circ} \mathrm{C}$ and $38{ }^{\circ} \mathrm{C}$ as shown in Scheme 2. The polymer brush which had a higher hydrated thickness would occupy the top of the mixed brushes modified surface, therefore the hydrophilic/hydrophobic property of the surface could be controlled by this exposed part. For PGNS/PGM mixed polymer brushes coating, the overall hydrophilic character of the mixed brush is provided by the highly hydrophilic PMOXA in the PGM. The PNIPAM block is an inherently responsive polymer chain and serves as a macromolecular trigger to bring the PSt hydrophobic part to the surface upon the change of external temperature above or below the LCST of PNIPAM. The PSt block is a hydrophobic probe. When PNIPAM is not swollen (e.g. at $38{ }^{\circ} \mathrm{C}$ higher than the LCST of PNIPAM), the hydrophobic probe with appropriate $M_{\mathrm{n}}$ of PSt block $\left(\mathrm{PGNS}_{6 \mathrm{k}}\right.$ ) would be hidden inside the hydrophilic PGM layer; when PNIPAM blocks are more extended $\left(e . g\right.$. at $0{ }^{\circ} \mathrm{C}$ lower than the LCST of PNIPAM), the hydrophobic probe of PSt would be exposed to the surface. Consequently, with $\mathrm{PGNS}_{6 \mathrm{k}} / \mathrm{PGM}$ mixed brushes, by tuning the environmental temperature from $38{ }^{\circ} \mathrm{C}$ to $0{ }^{\circ} \mathrm{C}$, the surface behavior could be changed from hydrophilic to hydrophobic.

\section{Adsorption of protein}

The effect of switching between hydrophilic and hydrophobic properties of the developed system on its adsorption of protein was investigated. To qualitatively assess the protein adsorption, a fluorescent test was performed using FITC-BSA, FITC-Fib and FITC-Lys as the model proteins, respectively. Fig. 4 shows the surface images by fluorescence microscopy after the adsorption of proteins at $0{ }^{\circ} \mathrm{C}$ and $38{ }^{\circ} \mathrm{C}$, respectively. The bar graphs are the relative quantitative analysis of the fluorescence intensities of the corresponding fluorescence images in Fig. 4. Herein the green fluorescence illustrates the adsorption of protein. For PGM modified surfaces, no adsorption was detected for all three types of protein (BSA, Fib, and Lys) at either $0{ }^{\circ} \mathrm{C}$ or $38{ }^{\circ} \mathrm{C}$, representing the strong anti-fouling property of PMOXA. For PGN modified polymer brushes, strong adsorption of proteins with the fluorescence intensity of $40 \%$ for BSA, $52 \%$ for Fib, $50 \%$ for Lys was observed at $38{ }^{\circ} \mathrm{C}$, but by changing the temperature to $0{ }^{\circ} \mathrm{C}$, very little adsorbed protein was observed (fluorescence intensity was only $1 \%$ for BSA, $11 \%$ for Fib, $19 \%$ for Lys) because of the protein-resistant ability of the hydrated layer of swollen PNIPAM in PGN. ${ }^{50-52}$ After the block copolymerization of PGN with PSt (PGNS), the adsorption of three proteins on PGNS modified substrates was observed at $0{ }^{\circ} \mathrm{C}$, while by shifting the temperature to $38{ }^{\circ} \mathrm{C}$, the protein adsorption amount was nearly the same as at $0{ }^{\circ} \mathrm{C}$, and the amounts of protein adsorbed on PGNS modified substrates increased with increasing the molar mass of PSt both at $0{ }^{\circ} \mathrm{C}$ and $38{ }^{\circ} \mathrm{C}$. In the mixed polymer brushes of PGN/PGM, no evident fluorescence was observed (fluorescence intensity was nearly $3 \%$ for BSA, $3 \%$ for Fib, $1 \%$ for Lys) both at $0{ }^{\circ} \mathrm{C}$ and at
$38{ }^{\circ} \mathrm{C}$ due to strong protein repellent property of exposed PGM. As long as mixed polymer brushes of PGNS/PGM were concerned, an almost negligible amount of adsorption of these three proteins was observed for $\mathrm{PGNS}_{1 \mathrm{k}} / \mathrm{PGM}$, both at $0{ }^{\circ} \mathrm{C}$ and at $38{ }^{\circ} \mathrm{C}$. For $\mathrm{PGNS}_{6 \mathrm{k}} / \mathrm{PGM}$, strong adsorption of protein was observed at $0{ }^{\circ} \mathrm{C}$ and its fluorescence intensity was $65 \%$ for BSA, $78 \%$ for $\mathrm{Fib}, 77 \%$ for Lys; while inconspicuous adsorption of protein took place by changing the temperature to $38{ }^{\circ} \mathrm{C}$ (fluorescence intensity was $8 \%$ for BSA, 9\% for Fib, 10\% for Lys). These results further demonstrated that the exposed PSt block was more hydrophobic at $0{ }^{\circ} \mathrm{C}$ which would result in strong protein adsorption and exposed PGM that was more hydrophilic at $38{ }^{\circ} \mathrm{C}$ would display a strong protein repellent property for $\mathrm{PGNS}_{6 \mathrm{k}} / \mathrm{PGM}$ mixed brushes as shown in Scheme 2. However, for $\mathrm{PGNS}_{8 \mathrm{k}} / \mathrm{PGM}$, where the molar mass of the PSt block was at its maximum, the same intensive fluorescence on $\mathrm{PGNS}_{8 \mathrm{k}} / \mathrm{PGM}$ was observed at either $0{ }^{\circ} \mathrm{C}$ or $38{ }^{\circ} \mathrm{C}$ for each protein (67\% for BSA, $84 \%$ for Fib, 95\% for Lys), due to the predominant role of the exposed PSt block irrespective of temperature as shown in Scheme 2. In brief, the adsorption degree of proteins on PGNS/PGM mixed brushes, regardless of acidic or basic protein (BSA/Lys), large or small size protein (Fib/Lys) could be adjusted through the hydrophobic/hydrophilic interaction between protein and the exposed part of mixed brushes by varying the temperature of the environment.

The quantification of the adsorption of protein was performed by using VASE. To verify the reliability of this method, after measuring the dry thickness of polymer modified wafers, the same wafers were immersed in PBS solution (without protein) for $2 \mathrm{~h}$ at $0{ }^{\circ} \mathrm{C}$ or $38{ }^{\circ} \mathrm{C}$, then its thickness was remeasured after being dried under nitrogen at $25{ }^{\circ} \mathrm{C}$. The results showed no considerable difference in thickness, suggesting the validity of this method. The details of the experiment and the corresponding results are shown in the ESI. $\dagger$ The ellipsometry thickness of polymer modified silicon wafers before and after BSA, Fib and Lys adsorption at $0{ }^{\circ} \mathrm{C}$ and $38{ }^{\circ} \mathrm{C}$ are shown in Fig. S8 of the ESI, $\dagger$ and the amounts of protein adsorption calculated by eqn (1) were shown in Fig. 5. As shown in Fig. 5, the amounts of protein adsorption on the PGM modified surfaces remain nearly the same at either $0{ }^{\circ} \mathrm{C}$ or $38{ }^{\circ} \mathrm{C}$, representing the strong protein repellent properties of PMOXA. The amounts of protein adsorbed on PGN at $0{ }^{\circ} \mathrm{C}$ were lower than that adsorbed at $38{ }^{\circ} \mathrm{C}$, indicating that the hydrophobic interaction between PGN and proteins could be adjusted through the thermoresponsive ability of PNIPAM. Similar to fluorescence microscopy results, the amounts of protein adsorbed on PGNS modified wafers increased with increasing the molar mass of PSt block at either $0{ }^{\circ} \mathrm{C}$ or $38{ }^{\circ} \mathrm{C}$. In the mixed polymer brushes of PGN/PGM, a little adsorption of protein (nearly $10 \mathrm{ng} \mathrm{cm}^{-2}$ for BSA, $30 \mathrm{ng} \mathrm{cm}^{-2}$ for Fib, $10 \mathrm{ng} \mathrm{cm}^{-2}$ for Lys) was observed both at $0{ }^{\circ} \mathrm{C}$ and $38{ }^{\circ} \mathrm{C}$. While in the mixed polymer brushes of $\mathrm{PGNS}_{1 \mathrm{k}} /$

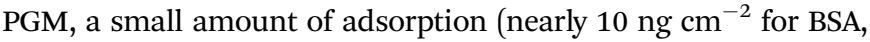

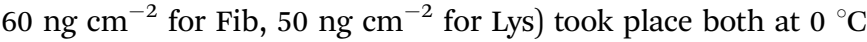
and at $38{ }^{\circ} \mathrm{C}$. However, by increasing the molar mass of PSt in the mixed polymer brushes $\left(\mathrm{PGNS}_{6 \mathrm{k}} / \mathrm{PGM}\right)$, a large amount of protein 
(a) BSA

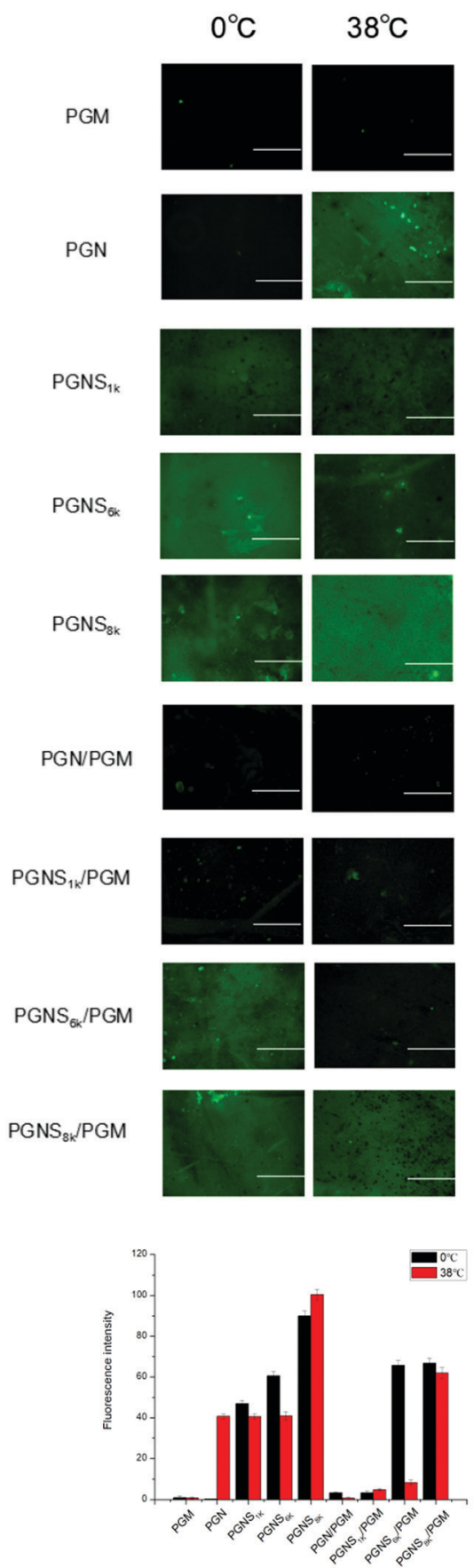

(b) Fib
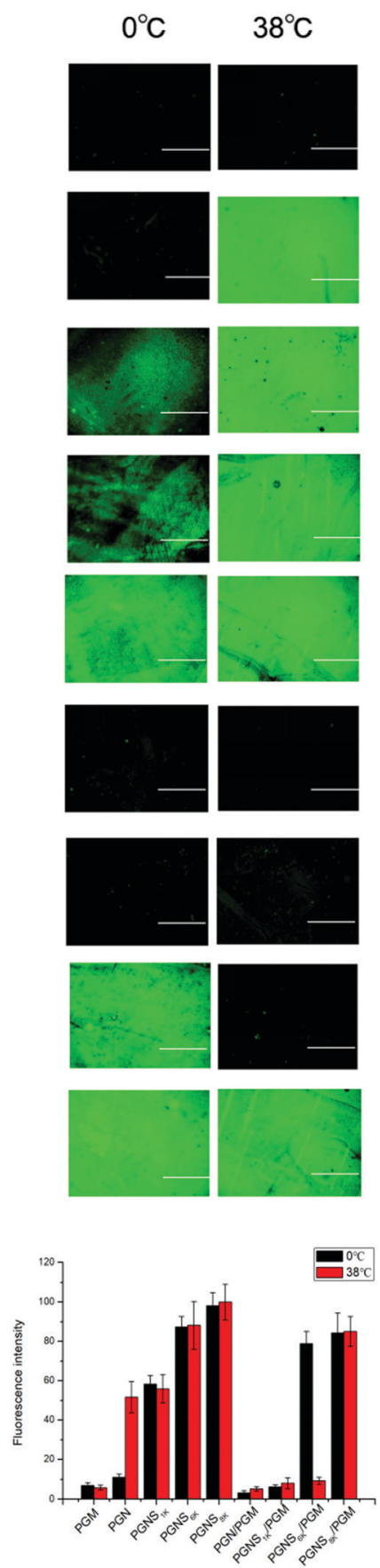

(c) Lys
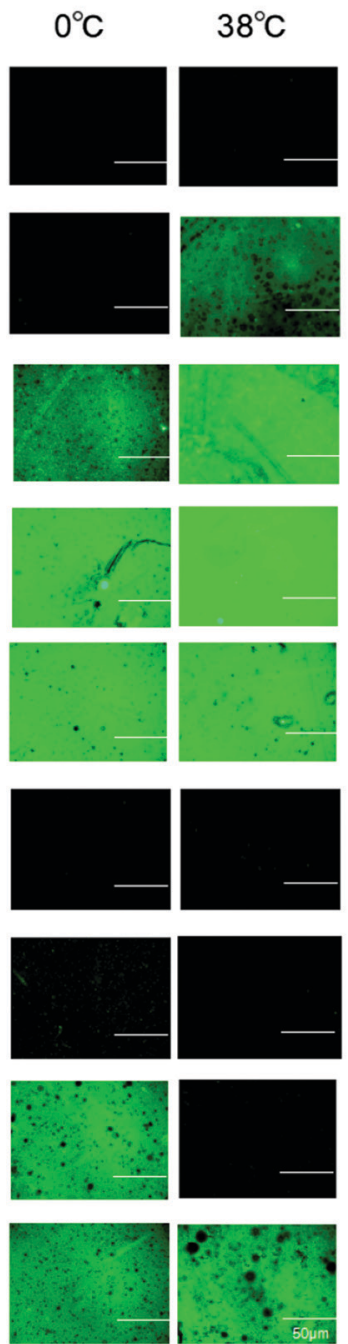

Fig. 4 Fluorescence microscopy images and fluorescence intensity bar graph of the (a) FITC-BSA, (b) FITC-Fib and (c) FITC-Lys adsorption on PGM, PGN, PGN/PGM, PGNS ${ }_{1 k}, P G N S_{6 k}, P G N S_{8 k}, P G N S_{1 k} / P G M, P G N S_{6 k} / P G M$, and PGNS $8 k / P G M$ modified glass wafer at $0{ }^{\circ} \mathrm{C}$ and $38^{\circ} \mathrm{C}$. Scale bar is $50 \mu \mathrm{m}$. The fluorescence intensity of $\mathrm{PGNS}_{8 \mathrm{k}}$ at $38{ }^{\circ} \mathrm{C}$ was set as $100 \%$ for each protein. Data are expressed as mean \pm SD $(n=3)$.

adsorption (207 $\mathrm{ng} \mathrm{cm}^{-2}$ for BSA, $700 \mathrm{ng} \mathrm{cm}^{-2}$ for Fib, $408 \mathrm{ng} \mathrm{cm}^{-2}$ for Lys) was observed at $0{ }^{\circ} \mathrm{C}$, but by changing the temperature to $38{ }^{\circ} \mathrm{C}$, the amounts of protein adsorbed on PGNS $_{6 \mathrm{k}} / \mathrm{PGM}$ decreased sharply (11 $\mathrm{ng} \mathrm{cm}^{-2}$ for BSA, $83 \mathrm{ng} \mathrm{cm}^{-2}$ for Fib, $77 \mathrm{ng} \mathrm{cm}^{-2}$ for Lys), representing its strong temperature responsive antifouling properties. By further increasing the molar mass of PSt, considerable amounts of protein adsorbed on $\mathrm{PGNS}_{8 \mathrm{k}} / \mathrm{PGM}$ were observed at either $0{ }^{\circ} \mathrm{C}$ or $38{ }^{\circ} \mathrm{C}$, and the amounts of protein adsorbed on $\mathrm{PGNS}_{8 \mathrm{k}} / \mathrm{PGM}$ are of the same order of magnitude at both $0{ }^{\circ} \mathrm{C}$ and $38{ }^{\circ} \mathrm{C}$ as shown in Fig. 5. These results were fairly consistent with the observations obtained from fluorescence microscopy. Finally, the $\mathrm{PGNS}_{6 \mathrm{k}} / \mathrm{PGM}$ shows 

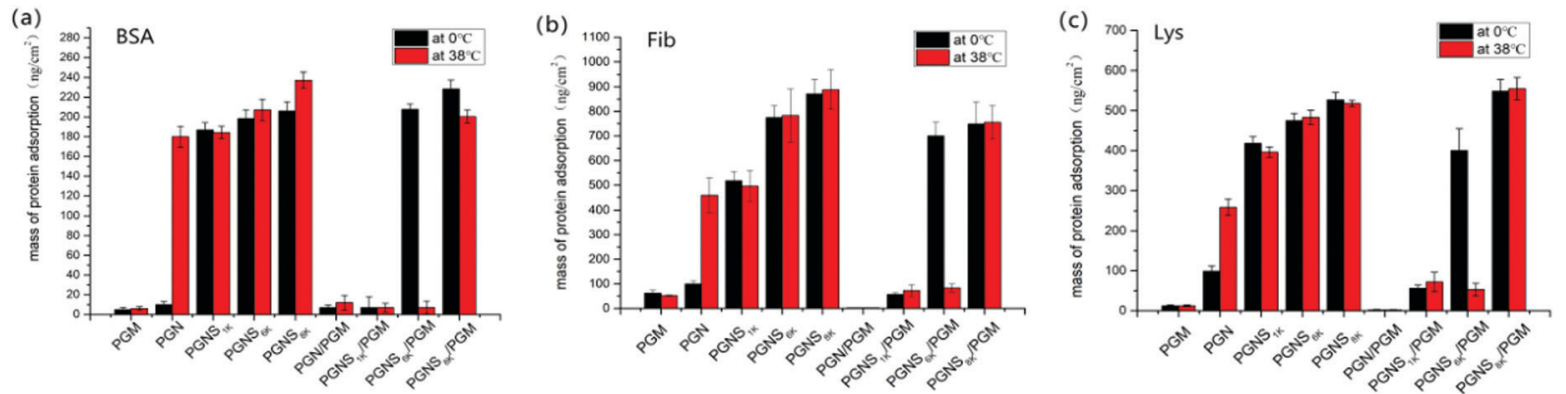

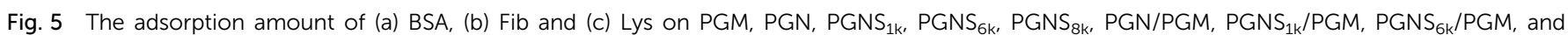
$\mathrm{PGNS}_{8 \mathrm{~K}} / \mathrm{PGM}$ modified silicon wafers at $0{ }^{\circ} \mathrm{C}$ and $38{ }^{\circ} \mathrm{C}$, respectively, obtained by using VASE. Data are expressed as mean $\pm \mathrm{SD}(n=3)$.

the most attractive thermally responsive property and excellent stability (Fig. S9 and S10, ESI $†$ ), having important implication in developing chemically modified surfaces.

\section{Conclusions}

In this study, a mixed polymer brushes coating with thermoresponsive ability was fabricated by spin coating a mixture of PMOXA-r-GMA and PGMA- $b$-PNIPAM- $b$-PSt solutions onto silicon or glass substrates followed by an annealing protocol via GMA units as the anchor part. Under the selected temperature (below or above the LCST of PNIPAM), the hydrophilic/hydrophobic behavior of mixed brushes in an aqueous environment was mainly governed by the exterior part through varying the molar mass (i.e. chain length) of the PSt block. When the environment temperature remained below the LCST of PNIPAM, the PNIPAM block was swollen. The hydrated thickness of the PGMA- $b$ PNIPAM- $b$-PSt brush increased with increasing the molar mass of PSt. When the hydrated thickness of PGMA- $b$-PNIPAM- $b$-PSt with lower molar mass of PSt block $\left(\mathrm{PGNS}_{1 \mathrm{k}}\right)$ was lower than that of PMOXA-r-GMA, the surface showed hydrophilic behavior; when the hydrated thickness of PGMA- $b$-PNIPAM- $b$-PSt with higher molar mass of PSt block $\left(\mathrm{PGNS}_{6 \mathrm{k}}\right.$ and $\mathrm{PGNS}_{8 \mathrm{k}}$ ) was higher than that of PMOXA-r-GMA, the surface showed hydrophobic behavior. When the environment temperature remained above the LCST of PNIPAM, the PNIPAM block collapsed. The surface only displayed the hydrophobic behavior when the hydrated thickness of PGMA- $b$-PNIPAM- $b$-PSt with the maximum molar mass of the PSt block $\left(\mathrm{PGNS}_{8 \mathrm{k}}\right)$. The reversible transition between hydrophilic and hydrophobic behavior was realized for $\mathrm{PGNS}_{6 \mathrm{k}} /$ PGM mixed brushes in an aqueous environment upon temperature change (lower or higher than LCST of PNIPAM) through the reversibly exposing hydrophobic fragment at its hydrophilic surface. Moreover, switching of the exterior part for PGNS $_{6 \mathrm{~K}} / \mathrm{PGM}$ mixed brushes could be used to adjust the adsorption of proteins by tuning the environmental temperature (lower or higher than the LCST of PNIPAM). This strategy of reversibly exposing a fragment will lead to potential applications in coating design.

\section{Conflicts of interest}

There are no conflicts of interest to declare.

\section{Acknowledgements}

This work was supported by the National Natural Science Foundation of China (Grant No. 21674102).

\section{References}

1 P. Roach, D. Farrar and C. C. Perry, J. Am. Chem. Soc., 2006, 17, 617-621.

2 Z. Lei, J. Gao, X. Liu, D. Liu and Z. Wang, ACS Appl. Mater. Interfaces, 2016, 8, 10174-10182.

3 H. Chen, J. Yang, S. Xiao, R. Hu, S. M. Bhaway, B. D. Vogt, M. Zhang, Q. Chen, J. Ma, Y. Chang, L. Li and J. Zheng, Acta Biomater., 2016, 40, 62-69.

4 V. Bugatti, A. Sorrentino and G. Gorrasi, Eur. Polym. J., 2017, 93, 495-506.

5 N. M. S. Bettahalli, I. T. M. Arkesteijn, M. Wessling, A. A. Poot and D. Stamatialis, Acta Biomater., 2013, 9, 6928-6935.

6 S. Jana, B. J. Tefft, D. B. Spoon and R. D. Simari, Acta Biomater., 2014, 10, 2877-2893.

7 H. Chen, M. Zhang, J. Yang, R. Hu, Q. Chen, Y. Chang and J. Zheng, Langmuir, 2014, 30, 10398-10409.

8 H. Yuan, J. Xue, B. Qian, H. Chen, Y. Zhu and M. Lan, Appl. Surf. Sci., 2017, 394, 403-413.

$9 \mathrm{~J}$. Li, M. Li, J. Miao, J. Wang, X. Shao and Q. Zhang, Appl. Surf. Sci., 2012, 258, 6398-6405.

10 C. Alexander and K. M. Shakesheff, Adv. Mater., 2006, 18, 3321-3328.

11 B. Tripathi, N. Dubey, S. Choudhury, F. Simona and M. Stamm, J. Mater. Chem. B, 2013, 1, 3397-3409.

12 Y. Wang, J. Wu, D. Zhang, F. Chen, P. Fan, M. Zhong, S. Xiao, Y. Chang, X. Gong, J. Yang and J. Zheng, J. Mater. Chem. B, 2019, 7, 5762-5774.

13 A. Kikuchi and T. Okano, J. Controlled Release, 2005, 101, 69-84.

14 I. C. Alard, J. Soubhye and G. Berger, Polym. Chem., 2017, 8, 2450-2456.

15 M. F. Delcroix, G. L. Huet, T. Conard, S. DemoustierChampagne, F. E. Du Prez, J. Landoulsi and C. C. DupontGillain, Biomacromolecules, 2013, 14, 215-225.

16 M. F. Delcroix, S. Demoustier-Champagne and C. C. DupontGillain, Langmuir, 2014, 30, 268-277. 
17 D. Aulich, O. Hoy, I. Luzinov, K. J. Eichhorn, M. Stamm, M. Gensch, U. Schade, N. Esser and K. Hinrichs, Phys. Status Solidi C, 2010, 7, 197-199.

18 J. Draper, I. Luzinov, S. Minko, I. Tokarev and M. Stamm, Langmuir, 2004, 20, 4064-4075.

19 S. Minko, S. Patil, V. Datsyuk, F. Simon, K.-J. Eichhorn, M. Motornov, D. Usov, I. Tokarev and M. Stamm, Langmuir, 2002, 18, 289-296.

20 S. Minko, D. Usov, E. Goreshnik and M. Stamm, Macromol. Rapid Commun., 2001, 22, 206-211.

21 A. Sidorenko, S. Minko, K. Schenk-Meuser, H. Duschner and M. Stamm, Langmuir, 1999, 15, 8349-8355.

22 L. Ionov and S. Minko, ACS Appl. Mater. Interfaces, 2012, 4, 483-489.

23 O. Hoy, B. Zdyrko, R. Lupitskyy, R. Sheparovych, D. Aulich, J. Wang, E. Bittrich, K. Eichhorn, P. Uhlmann, K. Hinrichs, M. Muller, M. Stamm, S. Minko and I. Luzinov, Adv. Funct. Mater., 2010, 20, 2240-2247.

24 S. Lowe, N. M. O’Brien-Simpson and L. A. Connal, Polym. Chem., 2015, 6, 198-212.

25 L. Tan, L. Bai, H. Zhu, C. Zhang, L. Chen and Y. Wang, J. Mater. Sci., 2015, 50, 4898-4913.

26 H. Du, C. Zhang, K. Mao and Y. Wang, Talanta, 2017, 170, 275-285.

27 C. Pan, L. Chen, S. Liu, Y. Zhang, C. Zhang, H. Zhu and Y. Wang, J. Mater. Sci., 2016, 51, 2427-2442.

28 F. Mumtaz, C. Chen, H. Zhu, C. Pan and Y. Wang, Appl. Surf. Sci., 2018, 439, 148-159.

29 H. Zhu, F. Mumtaz, C. Zhang, L. Tan, S. Liu, Y. Zhang, C. Pan and Y. Wang, Appl. Surf. Sci., 2017, 426, 817-826.

30 A. A. Cavallaro, M. N. Macgregor-Ramiasa and K. Vasilev, ACS Appl. Mater. Interfaces, 2016, 8, 6354-6362.

31 L. Bai, L. Tan, L. Chen, S. Liu and Y. Wang, J. Mater. Chem. $B, 2014,2,7785-7794$.

32 H. Zou, S. Lin, Y. Tu, G. Liu, J. Hu, F. Li, L. Miao, G. Zhang, H. Luo, F. Liu, C. Hou and M. Hu, J. Mater. Chem. A, 2013, 1, 11246-11260.

33 E. Soto-Cantu, B. S. Lokitz, J. P. Hinestrosa, C. Deodhar, J. M. Messman, J. F. Ankner and S. M. Kilbey II, Langmuir, 2011, 27, 5986-5996.
34 B. S. Lokitz, J. Wei, J. P. Hinestrosa, I. Ivanov, J. F. Browning, J. F. Ankner, S. M. Kilbey and J. M. Messman, Macromolecules, 2012, 45, 6438-6449.

35 B. Wang, Z. Ye, Q. Xu, H. Liu, Q. Lin, H. Chen and K. Nan, Biomater. Sci., 2016, 4, 1731-1741.

36 A. Krieg, E. Arici, N. Windhab, J. H. Schattka, S. Schubert and U. S. Schubert, ACS Comb. Sci., 2014, 16, 386-392.

37 W. Ji, N. Li, D. Chen, X. Qi, W. Sha, Y. Jiao, Q. Xu and J. Lu, J. Mater. Chem. B, 2013, 1, 5942-5949.

38 H. Omidian, J. G. Rocca and K. Park, Advances in superporous hydrogels, J. Controlled Release, 2005, 102, 3-12.

39 H. K. Ju, S. Y. Kim, S. T. Kim and Y. M. Lee, J. Appl. Polym. Sci., 2002, 83, 1128-1139.

40 T. Baltes, F. Garret-Flaudy and R. Freitag, J. Polym. Sci., Part A: Polym. Chem., 1999, 37, 2977-2989.

41 M. Heskins, J. E. Guillet and E. J. James, J. Macromol. Sci., 1968, A2, 1441-1445.

42 Y. H. Bae, T. Okano and S. W. Kim, J. Polym. Sci.: Polym. Phys., 1990, 28, 923-936.

43 H. Kuroki, I. Tokarev, D. Nykypanchuk, E. Zhulina and S. Minko, Adv. Funct. Mater., 2013, 23, 4593-4600.

44 F. Mumtaz, C. Chen, H. Zhu, M. Atif and Y. Wang, Chinese J. Polym. Sci., 2018, 36, 1328-1341.

45 O. Borozenko, C. Ou, W. G. Skene and S. Giasson, Polym. Chem., 2014, 5, 2242-2252.

46 S. Colak and G. N. Tew, Langmuir, 2011, 28, 666-675.

47 P. A. Cuypers, J. W. Corsel, M. P. Janssen, J. Kop, W. T. Hermens and H. C. Hemker, J. Biol. Chem., 1983, 258, 2426-2431.

48 H. Elwing, Biomaterials, 1998, 19, 397-406.

49 S. Sharma, R. W. Johnson and T. A. Desai, Langmuir, 2004, 20, 348-356.

50 S. Burkert, E. Bittrich, M. Kuntzsch, M. Muller, K. J. Eichhorn, C. Bellmann, P. Uhlmann and M. Stamm, Langmuir, 2010, 26, 1786-1795.

51 S. Chen, L. Li and C. Zhao, Polymer, 2010, 23, 5283-5293.

52 C. Xur, N. Yonet-Yanyeri, N. Brouette, M. Sferrazza, P. V. Braaun and D. E. Leckband, Langmuir, 2011, 27, 8810-8818. 